\title{
Beyond ecolabels: what green marketing can learn from conventional marketing
}

\author{
Emma Rex*, Henrikke Baumann \\ Environmental Systems Analysis, Chalmers University of Technology, 41296 Göteborg, Sweden
}

Accepted 25 May 2006

Available online 9 November 2006

\begin{abstract}
Ecolabels have emerged as one of the main tools of green marketing. Although a great deal of effort has been invested in making them more effective and efficient, the market share of ecolabelled products is still low, partly because they have been addressed mainly to 'green' consumers. In a theoretical exposition of marketing theory, we find that green marketing could learn from conventional marketing in discovering other means than labelling to promote green products. Examples include addressing a wider range of consumers, working with the positioning strategies of price, place and promotion and actively engaging in market creation.
\end{abstract}

(C) 2006 Elsevier Ltd. All rights reserved.

Keywords: Ecolabel; Green marketing; Promotion; Green consumer; Environmental policy

\section{Introduction}

Ecolabels are intended as a means for consumers to make choices that will reduce environmental impact and enable them to influence how products are made. In the Nordic Countries, there are ecolabels for 55 product groups and 2800 products. In Japan, 64 product groups have criteria established for ecolabels and more than 5000 products have been accepted [1]. The market for green products is generally considered to be both established and expanding. One example in the food sector is that the world market for ecological food products has an annual increase in sales of $20 \%$ [2]. This may seem impressive, indicating great interest on the parts of industry and consumers in products that will do less harm to the environment.

However, looking at the actual market shares of these products alters the picture. Except for a handful of product groups, the overall market share of ecolabelled products is low. The food sector has been pointed out as one of the

\footnotetext{
* Corresponding author. Tel.: +46 31772 8606; fax: +46 317722172. E-mail address: emma.rex@chalmers.se (E. Rex).
}

segments where the green market continued to grow when growth in other sectors discontinued [3]. Yet today ecolabelled food products make up only a few percent (up to $5 \%$ ) of sales in Europe [2,4]. This seemingly weak response from the market has led more than one industry representative to conclude that there is no market for green products.

Although a great deal of effort has been put into making ecolabelling schemes more effective and efficient, actual sales of ecolabelled products have remained at moderate levels. Does this modest share of ecolabelled products mean that the green dimension of products is an insufficient marketing incentive in promotional communication, or is it inadequately handled or even unfit for the marketing context? Is it possible to find other ways to market 'green' products?

\subsection{Method}

In order to analyse the issues raised, we reviewed the marketing literature and examined whether there are methods in conventional marketing literature that have been overlooked in the green marketing field. We did this by taking stock of the green marketing literature and its relation to conventional 
marketing literature. We conducted a literature survey, comparing conventional marketing literature with marketing literature that has an expressed aim to account for aspects of relevance to the impact of products on the environment.

Marketing literature is an extensive field. We surveyed conventional marketing theory on a general level, as described in comprehensive marketing literature by scholars such as Kotler et al. [5]. Green marketing literature does not yet contain more than a few general volumes (e.g. refs. [6,7]). Two strategies were used to supplement this literature with additional material on green marketing: searching in academic article databases and searching in selected journals. The databases used were Science Direct and Pro Quest, and our searches used a combination of environmental terms (green/environment/eco), marketing terms (marketing/promotion/market) and ecolabelling terms (environmental label/ecolabel). Journals with a special focus on marketing strategy and consumer marketing/behaviour were also searched for to find articles concerning green considerations in a marketing context.

Below, we go through the field of green marketing and ecolabels. This exposition enables us to present some theoretical explanations for the only moderate success of ecolabelling, seen from the green marketing perspective. After this, green marketing efforts are analysed from a conventional marketing perspective, using basic models in general marketing theory.

\subsection{Definitions of marketing}

Marketing has been called "the interface between consumption and production" [8: p. 9]. Marketing activities are involved with both production and consumption: they influence the product portfolio and the communication efforts of the producer [8]. Accordingly, marketing has a key role to play in the incipience of a product or service development process as well as at its 'end'. Production and consumption patterns in society are increasingly seen as crucial to our route to a sustainable future. Hence, as stated by Charter et al.: "Marketers have an involvement in the sustainability debate both at macro and micro level, even though they may not know it" [8: p. 9].

Another often used definition of marketing is that of the Chartered Institute of Marketing, which states that marketing is: "the management process responsible for identifying, anticipating and satisfying customer requirements profitably" [6: p. 27]. Based on this definition, Peattie defined green marketing in 1995 as: "the holistic management process responsible for identifying, anticipating and satisfying the requirements of customers and society, in a profitable and sustainable way" [6: p. 28]. More recent definitions of marketing emphasise the relationship with consumers; the need to attract new customers as well as to keep current ones [9].

The marketing process involves a broad set of activities in a firm. Kotler et al. define the marketing process as "the process of (1) analysing marketing opportunities; (2) selecting target markets; (3) developing the marketing mix; and (4) managing the marketing effort" [5: p. 93]. Hence, the marketing process covers issues ranging from strategic to tactical.
The aim of green marketing is to include environmental issues in the marketing efforts. The idea is that if we provide consumers with better information about the green properties of the products offered, for example by the use of ecolabels, they can (and will) include this information in their purchasing decisions. This, in turn, will push companies to produce products that are better from an environmental point of view.

\section{Green marketing}

Green marketing dates back to the early 1970s [6]. Yet it was not until 1990 that green marketing "arrived in earnest" [10: p. 46]. In the early 1990s, many different aspects of green marketing were discussed academically. It was concluded that more research was needed on, for example, promotion [11] and consumer needs [12].

However, the main focuses of the green marketing literature in the late 1980s and early 1990s came almost exclusively to be the size of the green market and the 'profile' of the green consumer. Some scholars even say that the consumer profile was the only area of interest in studying the greening of the consumer [13]. Surveys showed extensive 'green market' potential. Margrath referred, in 1992, to a study showing that " $93 \%$ of adults consider a product's environmental impact important when they purchase something" [14: p. 31] and the same year Peattie reported that in developed countries, up to $75 \%$ of the population used environmental criteria regularly in some purchase decisions [10]. Simintiras et al. (1994) recalled that $42 \%$ of UK consumers chose products on the basis of their environmental performance and that " $27 \%$ of British adults were prepared to pay up to $25 \%$ more for 'environmentally friendly' products" [11: p. 415]. And so on.

The green market identified was typically divided into market segments based on the 'greenness' of the consumer $[8,10,11]$. Tables 1 and 2 give two examples of such consumer typologies.

\subsection{Characteristics of the green consumer}

Another area that attracted a great deal of interest early on was the characteristics of the green consumers. Numerous such studies were made. Diamantopoulos et al. summarised socio-demographic surveys made in 1966-1994 to describe the green consumer and found, among others, 39 studies on education, 31 studies on sex, 35 about age, and 21 surveys

Table 1

Share of consumers according to typology by Ogilvy and Mather (in ref. [10] (1992))

\begin{tabular}{lll}
\hline Consumer typology by Ogilvy and Mather \\
\hline $16 \%$ & Activists & Likely to buy green products and services \\
$34 \%$ & Realists & $\begin{array}{l}\text { Are worried about the environment } \\
\text { but sceptical about the green bandwagon }\end{array}$ \\
& Complacents & $\begin{array}{l}\text { See the solution as somebody else's problem } \\
28 \%\end{array}$ \\
$22 \%$ & Alienated & Are unaware of green issues or see them \\
& & as transient \\
\hline
\end{tabular}


Table 2

Share of consumers according to typology by US Roper Starch Worldwide 2000 (in ref. [8])



dealing with social class [15]. (See also Straughan and Roberts for a similar compilation [16]).

Many of the surveys aimed at identifying typical demographic qualities of the green consumer. For example, females, young people and people with a relatively high education and income were identified as most likely to engage in green consumer behaviour [16]. However, in the plethora of surveys made, many contradictory views of the probable green consumer were put forward $[16,17]$.

There are also surveys, notably more recent ones, using psychographic characteristics such as political orientation and environmental concerns to identify the green consumer. Such characteristics turned out to be better at explaining variations in green consumer behaviour than demographic criteria [16]. Perceived consumer effectiveness (i.e. the individual's belief that his or her efforts will make a difference) has been particularly pointed out as being useful in predicting actual buying behaviour [16-18]. Another somewhat different approach to finding the green consumer was used by Solér, who concluded that the extent and nature of 'ecological cues', i.e. experiences of environment-related problems, were decisive to their buying behaviour [19].

\subsection{The green backlash}

The enthusiasm for the big green market had barely begun to develop before reports on significant problems, negative publicity and an eroded green premium appeared [12,20,21]. The willingness to pay extra for green products was less than anticipated. Actual sales of green products turned out to be much smaller than reported by the consumer surveys: the few statistics that exist on actual sales of green products are more recent, but it has been concluded that the market share for green products has not changed significantly over the past decade (e.g. ref. [22]). In addition to the low market shares, environmental claims in advertisements, for instance, were often met with criticism from competitors and consumer organizations [23], as well as regulatory resistance and sometimes even legal action [12,24]. Industry also had numerous reports of consumers being distrustful and suspicious of environmental advertising and claims $[11,25]$. Davis summarised the problems as two categories: overly complex and divergent rules regarding green marketing and advertising, and unenthusiastic consumer response [12].

In the early 1990s, it was a common belief that the way to overcome the problems of mistrust and multiple rules was to seek more consistent and appropriate regulations and standards [12]. Many organisations, including governmental organisations, NGOs, trade associations and engineering and policy researchers, grappled with this information problem, resulting in the development of instructions and regulations for correct use of environmental terms and emblems (see e.g. refs. $[26,27])$, environmental labelling schemes to assess and inform about the environmental qualities of products $[11,28]$ and a standard for environmental labels and declarations (ISO 14020:2000) [29]. The area of environmental labels also attracted psychologists who were curious about the psychological determinants for the choice or non-choice of ecolabelled products.

Davis argued that the problem of complex and divergent rules was significant, but not determinant for market success [12]. Instead he asserted that companies should deal with consumer response by understanding and satisfying consumer needs. However, this part of the problem received very little academic attention, and then mainly from researchers in psychology and sociology, who explained why consumers were so positive in the survey but did not buy green products at the end of the day.

\subsection{Attitudes and behaviour}

Attempts to explain the gap between consumers' reported attitudes and their actual buying behaviour have been the main focus in the green faction of consumer psychology. A model often used in this line of research is Ajzen's 'Theory of Planned Behaviour' (e.g. ref. [30]). According to this theory, intentions towards an act are determined by attitudes, subjective norms and perceived control. Intention, in turn, may lead to certain behaviour. However, many factors can interfere in this process, with an impact on whether or not the environmentally friendly attitude will result in actual behaviour (e.g. the purchasing of ecolabelled products). Factors identified as influencing this process include if the purchase is perceived as low-cost or high-cost [31], if the product is associated with earlier behaviours and habits [32], if the consumer perceives that there are alternative products [33] and whether or not the consumer trusts the environmental information provided [34].

After following green marketing research over the years, we conclude that most efforts have been related to the characteristics of individuals, in terms of green consumers, how many there are, how to identify them, and how they behave.

\section{Ecolabels}

It has been argued that green products have certain specific inherent negative characteristics that have to be overcome in order to market them successfully. One that has gained special focus is how to demonstrate the environmental qualities of the products [22]. Governmental and non-governmental organisations have recognised this information problem and made great efforts to facilitate the process, by introducing and maintaining trustworthy environmental labelling schemes. 
Along with this process, a body of research on the use and effectiveness of such environmental labels has developed. This research deals with the recognition and use of ecolabels, but seldom discusses ecolabels in a marketing context. The literature on ecolabels seems to have evolved to a large extent separately from marketing research. For example, green marketing accounts for 88 references in the Science Citation Index, spread equally over the years since the early 1990s. During the same time period, ecolabels account for 112 references, slightly increasing in frequency over the years. Only 31 references share both of these keywords.

There are various forms of ecolabels, including both mandatory and voluntary labels. One example of a mandatory label is the EU energy label, assessing the energy consumption for household appliances on a scale from A to F, where A means least energy consumption and $\mathrm{F}$ most energy consumption [1]. Voluntary labels are classified according to the ISO standard into three groups: type I, type II and type III [29]. Type I is what is most often referred to as ecolabels. These also seem to be the most often researched ones [35]. Type II are selfdeclared environmental claims, and Type III environmental product declarations where quantified environmental information is presented in a standardised way.

Environmental labels are used by a variety of stakeholders. For policymakers, labels are tools to create incentives for business to change the market [23]. They may also be a first step towards gradually increasing pressure on producers, e.g. from voluntary to mandatory labelling. Moreover, labels can be used by NGOs to put pressure on producers and consumers, or labelling initiatives may stimulate public debate [23]. For companies, the main motivation for using labels is often said to be competitive advantages or improved market shares [1].

Interest in ecolabels has been extensive. Academically, much effort has been invested in their design and use. The widespread interest in ecolabels is shown, for example, in a literature review by Leire et al. [36]. They found 144 studies and reports on product related environmental information in the Nordic countries only, the majority concerning ecolabelling schemes. Much of the research on ecolabels deals with how to make them more effective. Studied issues include whether or not consumers recognize various labels, if they understand their meaning and if they trust the label's message [35,37]. These issues have all been considered crucial to determining whether consumers will use a label as intended in their decision making [34]. It has also been concluded that labels will only influence decision making if the consumer desires environment-friendly products [34]. However, recent studies indicate that although some labels and regions fulfil all these criteria, this does not automatically lead to green purchasing decisions [35].

\subsection{Success or failure?}

The level of success of ecolabels can be assessed in various ways. There have been a number of surveys from various countries on consumer awareness of ecolabels [37]. It should be noted, however that the effect of ecolabels in terms of environmental performance has not been the subject of much research. It is also hard to find systematic data on the market share of green products.

Several publications have pointed out the lack of data or knowledge about whether or not ecolabels improve the overall environmental quality of society (e.g. refs. [1,37]). There have even been suggestions that ecolabels may be counterproductive, for example by acting as "barriers to environmental innovation" because the criteria are based on current products [38: p. 130]. However, for specific products or product groups, assessments can be found showing environmental improvements thanks to the introduction and use of ecolabels. For example, the food retailer Coop Sweden has stated that, as a result of consumers' choice of ecological food products during 2004, the amount of pesticides used for food production was reduced by $14,000 \mathrm{~kg}$ and the amount of artificial fertilizers by $1,000,000 \mathrm{~kg}$ [39]. A survey of changes in household detergents in Sweden showed decreased use of chemical products by $15 \%$ since the introduction of ecolabels for this product group and that the surfactants used had been replaced by more biodegradable ones [40]. One problem with these kinds of isolated examples is that it is hard to relate to 'ordinary' material flows such as total product sales and overall material flows in society. Another problem is to determine what improvements can be attributed to the existence of ecolabels. In the case of household detergents, the ecolabelling organisation had an expert panel to review the detergents survey and concluded, in a general way, that "the ecolabel had had significance for the changes" [41]. The expert panel, however, pointed out that the effects of the ecolabel should be seen in combination with other efforts [42].

Also for assessments of market penetration for ecolabels, information is fragmentary and covers a very limited number of products. It can be concluded that the share of ecolabelled products differs considerably with type of product and country. Some specific products in certain regions show a remarkable market share of green products: for example, the market share of ecolabelled printing paper is more than $70 \%$ in the Nordic countries [1], and in Sweden, the market share of ecolabelled laundry detergents is around 90\% [40]. On a more aggregated level, however, market penetration is much lower. Ekologiska Lantbrukarna (the Swedish ecological farmers' association) reports on a study of the share of organic food in some countries in Europe which found that organic (ecological) food only made up a few percent of the total food sales, ranging from $4.5 \%$ in Denmark to less than one percent in England [2]. Similar market shares (a few percent) for ecological food products have also been reported by Coop Norden [4]. Such a low market share could hardly be considered a success for green products. In fact, the sales of ecological food products by Coop Norden even declined by 3.4\% in 2004 [4].

\section{Theoretical explanations from the green perspective}

After finding that the market share for green products was relatively low, we searched for explanations given in the green marketing and ecolabelling literature and found that they were 
mainly of two kinds: the market for green products is either non-existent or saturated and the environmental information given needs to produce more efficient results.

\subsection{The green market: Saturated or non-existent?}

From a green marketing perspective, the low share of green products sold is explained by the modest size of the green market segment. In this view, environmental awareness is considered a precondition for green purchasing, and the small increase in market shares for green products has been explained by saying that the number of truly green consumers is not rising [22]. As mentioned in Section 2, the 'true blue greens' are only about $10-15 \%$ of consumers. Not even all product groups have green alternatives, so we cannot expect higher general market shares than a few percent as long as this segment of consumers remains limited.

It is not surprising therefore to find the argument that there is no market for green products and that consumers in general have never really cared about environmental qualities of products. For example, Neff argues that marketers launching green products in the 1990s did so as a response to a "media hype about the environment" [43: p. 16].

More recently, it has been questioned whether it is at all relevant to talk about green consumers. It is argued that green is not a fixed character of a consumer. The context in which the purchase is made is of great importance for whether or not people will chose the green alternative [17,22,32]. The same consumer may well make green purchase decisions in one situation but not in another. Green buying behaviour is not determined by the characteristics of consumer alone.

\subsection{More efficient ecolabelling needed}

Researchers into ecolabelling have focused on making environmental labels more effective as communication instruments to advance green products and efficient as a means of giving information to be taken into account in the purchasing situation. Rubik and Frankl found, that various environmental product information systems such as ecolabels need to be better interlinked and also linked to national and international policies [1]; Thøgersen emphasised the importance of consumer recognition, understanding and trust in ecolabels [34]. Improved consumer information tools are continuously being called for that are, for example, 'transparent' and 'non-misleading' [44].

Grankvist et al. take a somewhat different approach. Related to the discussion above about targeting segments, they found a difference in consumer response depending on whether the ecolabel is 'positive' or 'negative' [45]. Today's ecolabels are primarily positive: the label signals that the product is to be preferred to a non-labelled product. According to Grankvist et al., such information appeals to people who already have a strong environmental interest, while people with less environmental concern were sensitive to the negative labels, i.e. labels signalling that the product is disadvantageous from an environmental point of view [45]. (People with no environmental concern were indifferent to both positive and negative environmental information.) Given these findings, it may be possible to attune to more consumers by introducing negative environmental labelling schemes. This may to some extent explain the success of the mandatory energy label in the EU, which classifies all products on a scale from A (least energy consumption) to $\mathrm{F}$ (most energy consumption) (see ref. [1] for an assessment of this label's success).

\subsection{Looking for other means to increase the appeal of green products}

The motivation for more effective and efficient ecolabelling schemes has generally been that consumers need environmental information. As environmental qualities are often hidden characteristics, producers need to make them visible to consumers. According to this logic, the main task for the marketers is to find the green consumer and inform him or her about the products' environmental qualities. The extensive focus on profiling the green consumer and developing various forms of environmental labels fits well into this logic. The assumption is that ecolabelling provides the producers with a competitive advantage. It should be noted, however, that ecolabelling has turned into becoming a policy tool (see e.g. refs. $[1,34,35]$ ), associated with great expectations as a means of changing consumption patterns on a voluntary basis. It is considered to be "one of the most promising forms of environmental information policy" [34: p. 286]. Although ecolabelling is seen as one of the main 'market based' means available to encourage greener production and consumption systems (for example in the Integrated Product Policy proposal currently being debated at EU level [46]), the role of eco labels are seldom discussed in a marketing context.

We think that neither ecolabelling nor environmental information is a goal in itself but a means of creating a more environmentally friendly production and consumption system, i.e. encouraging a greener market. Since market management is the home ground for marketers and market researchers, ecolabels need to be discussed in this context, especially in the light of the poor market performance of ecolabelled products so far. In order to view ecolabelling in this perspective, we compare green marketing and its focus on ecolabels with the more general body of literature on conventional marketing.

\section{Conventional marketing}

The marketing process includes a broad range of activities, ranging from strategic to tactical ones. In our discussions about green and conventional marketing we mainly use two basic concepts from conventional marketing: the marketing strategy and the marketing mix. We use these concepts as presented by Kotler et al. [5]. Many similar variations exist in the marketing literature.

The marketing strategy consists of a continuous loop where the sequence of demand measurement, segmentation, targeting and positioning result in competitive advantages (see Fig. 1). 


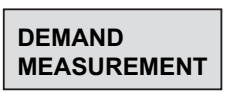

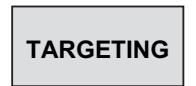

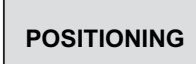

COMPETITIVE ADVANTAGE

Fig. 1. The marketing strategy (based on Kotler et al. [5]).

Once the strategy is developed, consumers are targeted by a proper marketing mix. The marketing mix is a well known concept in marketing. The mix includes the tactical marketing tools that a firm can control and use to influence the demand for their products. It consists of four groups of variables: product, price, place and promotion [5]. Using the framework given by the marketing strategy and the marketing mix, the propositions and the findings in green marketing research can be described as follows:

1. Demand measurement - The rise of green issues in the early 1990s led to numerous polls showing an increasing number of green consumers. These surveys measured market demand by identifying the size of the green market. Demand was mainly presented in terms of per cent of the consumers who reported themselves as being green.

2. Segmentation and targeting - Segmentation and targeting are closely related concepts. Market segmentation is the process of dividing a market into groups of consumers with different needs, characteristics or behaviours. In the targeting process these segments are evaluated and the company decides which segment or segments to address [5]. The green consumer typologies presented above (see Section 2) are examples of market segmentation on the basis of the green characteristics of the consumers. In line with general marketing theory, when the segments have been identified, the characteristics of these consumers need to be identified to allow for efficient positioning. As we have seen, great deal of effort in green marketing has also been put into identifying the characteristics of the green consumer.

3. Positioning - Once the green consumer has been identified, the product needs to be positioned on the market to appeal to this group. This is achieved through a careful design of the marketing mix: product, place, price and promotion. Promotion was recognised early as important in this perspective. However, ecolabels came to be the focus of the attempts to position green products.

\section{Green explanations from the conventional marketing perspective}

The account given in the previous section show that the activities made in green marketing fit into a general model of marketing strategy. Although all the phases in the marketing strategy have been covered by the work done in green marketing, the areas focused on represent only a limited number of the means available to marketers. These other means could prove significant for attaining higher market shares for green products. In order to gain a comprehensive understanding of the premises for a greener market, a more careful exposition of the elements of conventional marketing is made.

\subsection{The green market: already existing or in need of development?}

In conventional marketing, demand analysis includes not only the identification of the number of green consumers but also the analysis of current and future market opportunities. Although there have been some calls in the green literature for emphasising consumers' wants and needs [12,23], the dominant focus in green market research has been on determining the size and the characteristics of the green market.

In the general marketing literature, however, the market for a product is not considered to be limited to an existing number of interested consumers. Markets can be extended by attracting buyers who are currently unaware of or resistant to the product, by finding and communicating new applications of existing products and by stimulating increased use of the product [5]. It has also been argued that customers often do not know what they want or what it is possible to do. Instead of responding to an existing demand, it is the task of the marketers to understand customer needs "even better than customers themselves do", to meet not only existing but also latent and future needs [5: p. 16]. One example is found when Sony state that they 'create' markets "by educating and communicating with the public" (Hamel and Prahalad 1994 in [5: p. 16]). This statement reflects the view that the company has an active role in shaping a market for its products. Such standpoints contrast with the green marketing literature, in assuming that there is an existing green consumer. The dilemma associated with a consumer who does not know what he or she wants has only occasionally been touched upon in the green literature (e.g. ref. [6]), but without any further discussion of how to analyse the actual needs or of the creation of green markets.

\subsection{Marketing means: product labelling or product promotion?}

The most tangible discrepancy between green and conventional marketing perspectives was found regarding positioning. When the green marketing field was still in its infancy in the early 1990s, various positioning strategies were discussed in the literature. It was concluded that more research was needed about all parts of the marketing mix. Promotion, i.e. advertising, sales promotion, publicity and personal selling, was especially pointed out as an area where there was no or very little research done $[11,13,25]$. A few attempts were made to fill this gap, e.g. by classifying existing advertisements [47], studying the effect of various kinds of appeal [48,49] and green consumer characteristics of special importance for advertising [25].

Although some promising results and expectations were raised about the effects of green advertisements [49,50], there 
seems to have been little further academic interest in the area of promotion of green products. It has been argued that when the green products launched in the early and mid 1990s failed, marketers lost faith [43]. This seems to be true for researchers on green product promotion as well. In the last decade, ecolabels have become the prevailing means used to position green products. Although intended to be used by industry and business, it should be remembered that environmental labels (especially type I) have developed into policy instruments rather than marketing means. In the general marketing literature, labels have a subordinate role as positioning tools. A label is considered part of the technical information attached to the product. As such it is classified as 'product' in the marketing mix [5], not as a promotion tool. The importance of labels for product positioning is not accentuated in the conventional marketing literature. Instead, the emphasis is on promotion. This stands in stark contrast against the emphasis placed on ecolabels in the more recent green literature.

Closely related to the discussion about whether or not a company can influence the size of the market is the question of whether or not companies can influence consumer needs through promotion. Advertising has been considered "...both a reflection of and a formative influence on our culture" (Pollay 1986 in [47: p. 22]). Illmonen clarifies the concepts by distinguishing between wants and needs [51]: our needs are basic and will not easily be changed. The role of marketers when promoting products is first to actualise the need and then to convince the consumers that the product concerned is the right means to satisfy that need. Marketers thus transform consumer need into product specific wants. In this sense, marketers cannot influence our needs, but the way to satisfy them (our wants) [51]. For simplicity, the term 'needs' is often used in a broad sense in the literature, in such a way that it includes the 'wants'.

Although they are one of the cornerstones of marketing, consumer needs and wants are surprisingly little discussed in the green marketing literature. Peattie and Crane make the same reflection about the practice of green marketing in industry, arguing that industry has focused on producing green products rather than products that consumers wanted [3]. The distinction between needs and wants still seems to be uncharted territory for most green market researchers. Instead of studying how to take advantage of this distinction for advancing greener production and consumption systems, green marketing research has emphasised the need for 'demarketing' or 'removing the need' (e.g. refs. [6,52]). The active creation of 'wants' seems, if discussed, to be considered potentially devastating to sustainable development (e.g. ref. [52]).

\subsection{Areas remaining to be explored}

The finding that the conventional marketing field has only partly been taken into account in its green counterpart reveals that there are areas remaining to be explored. Strategically, market demand measurements have been more focused on the number of existing green consumers than on market needs (and wants) and new market potentials. Tactically, focus has been on informing consumers about technical qualities and not on influencing consumers through promotion. In comparison with green marketing, conventional marketing seems both richer (in terms of means used) and more active (in terms of industry involvement).

Fig. 2 summarises the comparison of green and conventional marketing, using the framework of the marketing strategy suggested by Kotler et al. [5]. The figure illustrates that the past and current focal areas in green marketing have been the measurement of market size, identification of the green consumer and positioning through ecolabels. However, from the conventional marketing literature, other possible means of green marketing can be identified, including analysing current and potential market needs and wants and addressing not only an existing green consumer segment but also a broader range of consumers. For positioning, green marketing has focused on the product and on the use of ecolabels to inform about green credentials. In addition to the product offered, conventional marketing literature emphasises the whole range of the marketing mix, for example pricing decisions (price), distribution channels and assortments (place) and advertisement, publicity and sales promotion (promotion) [5]. Adding these other marketing means to green marketing could give rise to new possibilities of gaining competitive advantages.

Historical examples of successful 'green' products support the recommendation to broaden the marketing means used, and provide examples of various alternative ways to market green products. One example, from Coop Sweden, shows how a company can shift consumers' wants to increase the market share for products with environmental credentials. In 2003, Coop launched a campaign to increase the sales of ecological eggs, including commercials on Swedish television and banners and posters in the stores. By the end of the year, eggs were the ecological product with the highest increase in sales
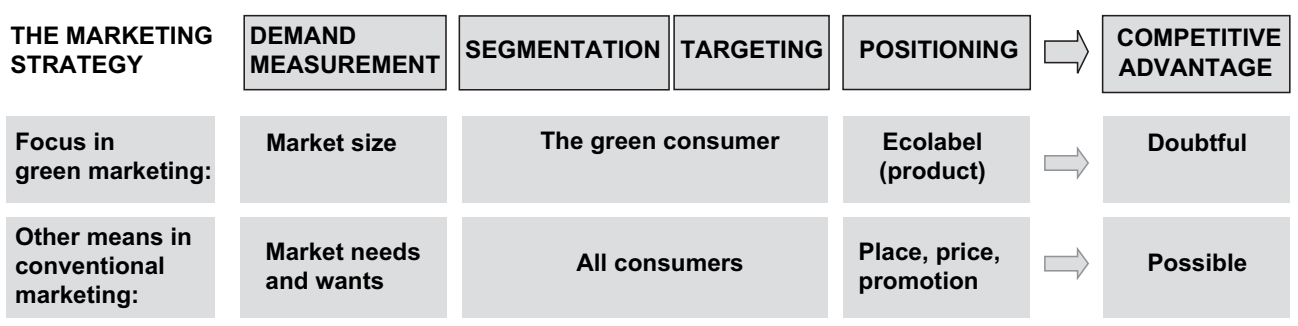

Fig. 2. The marketing strategy from two perspectives: current and past focal areas in green marketing and examples of additional marketing means suggested in the conventional marketing literature. 
(58\%) and a market share of $21 \%$ of all eggs sold at Coop [53]. This should be compared with the average market share of ecological food products by this retailer, which was $2 \%$ of sales in 2003.

Another example is presented by Meyer [22]. Among the identified success factors of NATURALine green clothing collection in Switzerland were the absence of a green price premium (same price as conventional clothes), enlarged range of NATURALine products in the stores (place) and advertising slogans (promotion). The analysis by Meyer highlights the benefits of working with other positioning strategies than ecolabelling the product. (Although Meyer uses another terminology, that of cost-benefit-analysis, the work fits well with the marketing mix framework).

\section{Furthering green marketing}

The analysis made here unveils two contrasting perspectives on green marketing: on one hand informing green consumers (by the use of ecolabels), on the other a co-evolution of supply and demand for products offered. The first perspective seems to have been the dominant one in green marketing research. The second is derived from the general marketing literature and is seen to having a potential for developing green marketing.

There are at least two limitations to viewing consumers as already green, given that the aim is to move beyond small niche markets for greener products. First, there seems to be an assumption that the consumer should be the active party in increasing green production and consumption. Governments and NGOs may help protect consumers from false market claims by developing ecolabels, guidelines and legal action. According to this view, it becomes the consumer's responsibility to be environmentally conscious and favour green products. Also, when companies nowadays often claim that 'there is no market for green products', they indicate that the process of greening production and consumption should start with consumer demand. Second, it may be questioned whether an exclusive focus on ecolabels is the best way to tell consumers about the green dimension of the product or whether it is only a way to inform already green consumers.

\subsection{Co-evolution of supply and demand}

Taking conventional marketing theory as the starting point alters the picture. Recalling that supply and demand are a result of mutual influences from producers and consumers, the way to target consumers can be modified. Instead of presupposing the existence of an already green consumer, consumer needs must be analysed carefully before possible offers are designed and promoted. Such an approach may hopefully shift industry opinion away from a passive statement that there is no demand for green products to a more active design of greener markets in line with consumers' environmental interests.

In this perspective, technical environmental information will not be at the centre of the attempts, but rather a careful analysis of consumers' and society's needs, design of suitable 'wants' and creative promotion strategies. This will require the use of a variety of tools from the conventional marketing toolbox. Broadened use of marketing strategies will hopefully also allow for a wider range of consumers to be targeted.

\subsection{Broaden green marketing}

It has been pointed out repeatedly by prominent groups in society that we need to change our current production and consumption patterns to achieve sustainable development [54]. To attain any major shift, we cannot rely on a minor share of true blue green consumers. With this in mind, the one-sided focus on ecolabels is problematic.

It may be time to rethink green marketing: from targeting green consumers with green products to broadening the targeted consumer group and including green properties as one of the appeals among others, of a product. This will require an extended set of marketing tools and a more active role for businesses.

We do not argue that the responsibility for greener production and consumption lies entirely with industry. However, we conclude that there are marketing means left to be explored by businesses and researchers given that they want to use green product qualities to gain market advantages. To designate one actor as responsible for the greening of production and consumption processes is probably not the right way to describe the problem. This presumes that the responsibility is attached to one single stakeholder such as consumers, companies or policymakers. Each such stakeholder is actually many actors or individuals, each influencing the other. Instead, the solution will be found in the interaction among various stakeholder groups.

\section{Conclusions}

Ecolabels have emerged as one of the dominant means of market communication for green credentials of products, but a sustainable production and consumption system is still far away. In this article we have tried to look beyond ecolabels in both time and place by comparing two fields of literature and looking for concrete results.

We have observed diverging ways of understanding the green market and diverging views on the potential of ecolabelling. A great deal of effort has been invested in making ecolabels more effective. However, we cannot expect high market shares for green products in general if the marketers continue to rely only on ecolabels and already green consumers. From a marketing perspective, ecolabelling is seen as technical information to the product with a subordinate role in marketing, hardly a means of making all products greener. To achieve greener production and consumption patterns we need to address a wider range of consumers than the deep green segment. We recommend broadening the means of green marketing and exploring various areas of marketing theory, such as the analysis of consumer wants and promotion.

We welcome further research on green market communication between consumers and the business community. In this 
communication more emphasis should be placed both on promotion by businesses and on how businesses deal with signals from the market. Such emphasis is important both theoretically and empirically, e.g. in determining whether or not special attention is needed to green issues and whether there is a difference in how companies analyse market signals related to green qualities compared to more traditional product qualities. Research on how to analyse consumer needs and possible market opportunities as well as on the effects of various kinds of promotional strategies on consumer behaviour is also needed. To obtain more substantial changes in our production and consumption systems, we cannot rely solely on making the existing labels more effective and efficient, but need to follow other avenues of market communication and research.

\section{Acknowledgements}

This research is part of the research program FLIPP: Furthering Lifecycle Considerations Through Integrated Product Policy. We are grateful to the Swedish Environmental Protection Agency for funding this program. We also want to thank two anonymous reviewers for their valuable comments on a previous version of this article.

\section{References}

[1] Rubik EF, Frankl EP, editors. The future of eco-labelling. Sheffield: Greenleaf Publishing; 2005.

[2] Ekologiska Lantbrukarna. Växande marknad: det aktuella marknadsläget för ekologiska livsmedel [A growing market: market share for ecological food products]. Sweden: Ekologiska Lantbrukarna; 2002.

[3] Peattie K, Crane A. Green marketing: legend, myth, farce of prophesy? Qualitative Market Research: An International Journal 2005;8(4):357-70.

[4] Coop Norden. Coop Norden 2004 En kort verksamhetsbeskrivning samt årsredovisning [2004 Annual Report Coop Norden], 2005.

[5] Kotler P, Armstrong G, Saunders J, Wong V. Principles of marketing. 3rd European ed. Harlow: Prentice Hall; 2001.

[6] Peattie K. Environmental marketing management: meeting the green challenge. London: Pitman Publishing; 1995.

[7] Charter M, Polonsky MJ. Greener marketing. Greenleaf Publishing; 1999.

[8] Charter M, Peattie K, Ottman J, Polonsky MJ. Marketing and sustainability, Association with The Centre for Sustainability Design. UK: Centre for Business Relationships, Accountability, Sustainability and Society (BRASS); 2002.

[9] Belz FM. Sustainability marketing: blueprint of a research agenda. Technische Universität München; 2005.

[10] Peattie K. Green marketing. London: Pitman Publishing; 1992.

[11] Simintiras AC, Schlegelmilch BB, Diamantopoulos A. 'Greening' the marketing mix: a review of the literature and an agenda for future research. In: McDonagh P, Prothero A, editors. Green management a reader. London: The Dryden Press; 1994. p. 413-34.

[12] Davis JJ. Strategies for environmental advertising. The Journal of Consumer Marketing 1993;10(2):19-36.

[13] Iyer E, Banerjee B. Anatomy of green advertising. In: McDonagh P, Prothero A, editors. Green management a reader. London: The Dryden Press; 1993. p. 471-83.

[14] Magrath AJ. The marketing of the green. Sales and Marketing Management 1992;144(12):31.

[15] Diamantopoulos A, Schlegelmilch BB, Sinkovics RR, Bohlen GM. Can socio-demographics still play a role in profiling green consumers? A review of the evidence and an empirical investigation. Journal of Business Research 2003;56(6):465-80.
[16] Straughan RD, Roberts JA. Environmental segmentation alternatives: a look at green consumer behaviour in the new millennium. Journal of Consumer Marketing 1999;16(6):558-75.

[17] Peattie K. Golden goose or wild goose? The hunt for the green consumer. Business Strategy and the Environment 2001;10:187-99.

[18] Ottman JA. Empowering the people. In Business 2003;25(6):32.

[19] Solér C. Ecologically-friendly buying. In: Wolff R, Ytterhus BE, editors. Environmental management - where do we stand? Cappelen Akademisk Forlag; 1995. p. 259-83.

[20] Mendleson N, Polonsky MJ. Using strategic alliances to develop credible green marketing. Journal of Consumer Marketing 1995;12(2):4-18.

[21] Wasik J. Green marketing: market is confusing, but patience will pay off. Marketing News 1992;26(21):16-7.

[22] Meyer A. What's in it for the customers? Successfully marketing green clothes. Business Strategy and the Environment 2001;10:317-30.

[23] de Boer J. Sustainability labelling schemes: the logic of their claims and their functions for stakeholders. Business Strategy and the Environment 2003;12:254-64.

[24] Scammon DL, Mayer RN. Agency review of environmental marketing claims: case-by-case decomposition of the issues. Journal of Advertising 1995;24(2):33.

[25] Shrum LJ, McCarty JA, Lowrey TM. Buyer characteristics of the green consumer and their implications for advertising strategy. Journal of Advertising 1995;24(2):71.

[26] Lans MS. New laws on green marketing are popping up all the time. Marketing News 1993;27(4):22.

[27] Konsumentverket. Miljö i marknadsföring [green marketing]. Konsumentverket [Swedish Consumer Agency] Rapport 2000:4 Sweden: Konsumentverket, 2000.

[28] Ecolabelling SIS. Get to know the swan - facts about the Nordic ecolabelling, SIS Ecolabelling; 2003.

[29] ISO. The ISO 14000 family of standards, guides and technical reports including drafts. 2002 Accessed September 2005; http://www.iso.org/iso/ en/prods-services/otherpubs/iso14000/family.pdf.

[30] Kalafatis SP, Pollard M, East R, Tsogas MH. Green marketing and Ajzen's theory of planned behaviour: a cross-market examination. Journal of Consumer Marketing 1999;16(5):441-60.

[31] Diekmann A, Preisendörfer P. Green and greenback. The behavioural effects of environmental attitudes in low-cost and high-cost situations. Switzerland/Germany: Institute of Sociology, University of Berne/Institute of Sociology, University of Rostock; 2000.

[32] Biel A, Larsson M, Gärling T. Köpbeteendets psykologi: Miljömedvetenhet och vanor [The psychology of buying behaviour: environmental consciousness and habits]. In: Ekström KM, Forsberg H, editors. Den flerdimensionella konsumenten [the multi-dimensional consumer]. Göteborg: Tre Böcker; 1999. p. 129-46.

[33] Rex E. The role of consumers in the market shift towards greener products. Göteborg: Chalmers University of Technology, Environmental Systems Analysis; 2002.

[34] Thøgersen J. Psychological determinants of paying attention of ecolabels in purchase decisions: model development and multinational validation. Journal of Consumer Policy 2000;23:285-313.

[35] Leire C, Thidell A. Product-related environmental information to guide consumer purchases - a review and analysis of research on perceptions, understanding and use among Nordic consumers. Journal of Cleaner Production 2005;13:1061-70.

[36] Leire C, Thidell Å. Consumer perceptions, understanding and use of product related environmental information. Nordic Council of Ministers; 2004.

[37] EVER. EVER study - interim report. EVER: project for the evaluation of EMAS and the eco-label for their revision, 2005 Accessed January 2006; http://europa.eu.int/comm/environment/ecolabel/pdf/news/ever_int erimreport.pdf.

[38] Erskine CC, Collins L. Eco-labelling: success or failure? The Environmentalist 1997;17:125-33.

[39] Coop Sweden. Miljökvitto 1, 2004 [Environmental receipt 1, 2004]. Accessed January 2006; http://www.coop.se/includefiles/MODULER/ CCMS/show_page.asp?iMappeID $=246 \&$ sSideNavn $=$ Milj\%F6kvitto + $\mathrm{I} \% 2 \mathrm{C}+2004$. 
[40] Hagenfors S. Hushållskemikalier i förändring En statistisk jämförelse mellan åren 1988 och 1996 [Changes in household detergents a statistical comparison between 1988 and 1996]. Svenska Naturskyddsföreningen, 1999 Accessed January 2006; http://www.snf.se/pdf/rap-bmvkemikalier.pdf.

[41] Svenska Naturskyddsföreningen [Swedish Society for Nature Conservation]. 10 år med Bra Miljöval-märkta tvättmedel [10 years with laundry detergents having the 'good environmental choice'-label]. 2003 Accessed January 2006; http://www.snf.se/bmv/om-framgangarutvardering96.cfm.

[42] Wilske A. Miljöutvärdering av Bra Miljöval för hushållskemikalier [Environmental assessment of the 'good environmental choice'-label for household detergents]. Göteborg: Scandiaconsult, 1999 Accessed January 2006; http://www.snf.se/pdf/bmv/rap-bmv-expertgrupp.pdf.

[43] Neff J. It's not trendy being green. Advertising Age (Midwest region edition) Chicago 2000;71(15):16.

[44] O'Rourke D. Market movements non-governmental organisation strategies to influence global production and consumption. Journal of Industrial Ecology 2005;9(1-2):115-28.

[45] Grankvist G, Dahlstrand U, Biel A. The impact of environmental labelling on consumer preference: negative vs. positive labels. Journal of Consumer Policy 2004;27(2):213-30.
[46] Commission of the European Communities. Integrated product policy: building on environmental life-cycle thinking. Communication from the Commission to the Council and the European Parliament; 2003.

[47] Banerjee S, Gulas CS, Iyer E. Shades of green: a multidimensional analysis of environmental advertising. Journal of Advertising 1995;24(2):21.

[48] Hartmann P, Ibáñez VA, Sainz JFF. Green branding effects on attitude: functional versus emotional positioning strategies. Marketing Intelligence and Planning 2005;23(1):9-29.

[49] Schuhwerk ME, Lefkoff-Hagius R. Green or non-green? Does type of appeal matter when advertising a green product? Journal of Advertising 1995;24(2):45.

[50] Zinkhan GM, Carlson L. Green advertising and the reluctant consumer Journal of Advertising 1995;24(2):1-6.

[51] Ilmonen K. Behov bland punkare och byråkrater: essäer från en konsumentforskares arbetsbord [Needs among punk-rockers and bureaucrats: essays from a consumer researcher]. Stockholm: Kooperativa inst; 1984

[52] Lebel L. Transitions to sustainability in production-consumption systems. Journal of Industrial Ecology 2005;9(1-2):11-3.

[53] Coop Sweden. Coop Sveriges Miljörapport 2003. [Coop Sweden Environmental Report 2003].

[54] Taylor B. Consumption: it is time for economists and scientists to talk. Journal of Industrial Ecology 2005;9(1-2):14-7. 